\title{
A Study of Some Cultural Differences between China and English- Speaking Countries
}

\author{
Yingxin Zhang* \\ International Department, Baotou Vocational \& Technical College, Baotou, Inner Mongolia, 014035, China
}

\section{ARTICLE INFO}

Article history

Received: 27 May 2020

Revised: 4 June 2020

Accepted: 9 October 2020

Published Online: 16 October 2020

Keywords:

Culture

Difference

Teaching

\author{
ABSTRACT \\ This paper emphasizes the importance of cultural teaching in English \\ teaching, and discusses some cultural differences between Chinese \\ and English from the perspective of colors, numbers, table manner, the \\ most important festival and animal connotation for our English teaching \\ purposes.
}

\section{Introduction}

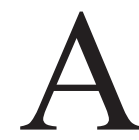
$\mathrm{t}$ a time of global cultural integration, with the rapid development of social economy, cultural exchanges between China and foreign countries are becoming more and more frequent. The world is getting smaller. People of different cultural backgrounds can't avoid the problems of cultural differences in communication.

As one of the most widely used means of communication in the world, English plays an increasingly unique role in the process of cultural exchange. In foreign communication, we can't master English well if we do not understand the culture contained in English. So if we want to learn to communicate in English, we must understand the cultural background of English-speaking countries, understand the cultural differences between China and foreign countries, and improve our ability of cross-cultural communication. Only in this way can we ensure the effectiveness and smoothness of communication.

In the English teaching in China, teachers particularly pay attention to teaching the denotation of words and

*Corresponding Author:

Yingxin Zhang,

Female, Native of Yingkou county, Liaoning province, Associate professor, Master of English language and literature, Shanghai international studies university;

Research interests: Translation, Interpretation, American and American culture, Literature and English teaching;

E-mail: zhangyingxin777@163.com.

Fund Project: This research project belongs to 2019 the special topic of English subject set up by Inner Mongolia Higher Education Academy. 
grammar, and seldom study the Western background culture and the connotation of words. In addition, our traditional culture and Western traditional culture are quite different, these reasons will lead to our students lack the necessary understanding of Western traditional culture, once we communicate with foreign friends, there will be pragmatic failure and even misunderstanding. For example, when a young business English major girl accompanied her company's clients on a tour of the Great Wall, an English man wants to go to the toilet, but he is too shy to ask directly where the toilet is. He put it tactfully: "Excuse me, may I go somewhere?" The translator thought: The Great Wall has arrived, where else can he go? And so she replied frankly: "Of course, you can go anywhere." She doesn't know it means: "Sure, you take a dump anywhere."

Therefore, in our English teaching, we have to tell the students about the British and American cultural knowledge, but also clear about the connotation of words. For example, our country once exported "White Elephant" batteries to the English-speaking countries, and no one wanted to buy it. In fact, white elephant means something useless and unwanted to the English-speaking people.

We should also make a comparative study between British and American culture and Chinese culture to find out the similarities and differences, to better understand Chinese and English culture, and to reduce the obstacles and difficulties in communication.

\section{Color Cultural Connotation}

Many colors have different meaning between China and English-speaking countries.

In the mind of the Chinese people, "red" is auspicious, festive, widely used in weddings, and festivals. But in English, red means danger, anger, like red figure, the meaning of deficit, and "see red", which means "get angry". In China, we express jealousy with red-eyed, say, red-eyed illness, whereas Englishmen use green-eyed. We say red tea while English says black tea. In China, yellow novels mean erotic novel. However, in English-speaking countries, blue novels have the same meaning ${ }^{[1]}$.

\section{Lucky Number}

Just like people all around the world, Chinese people traditionally associate luck with various numbers. Lucky numbers are based on Chinese words that sound similar to other Chinese words. The lucky numbers have auspicious meanings because their names sound similar to words that have positive meanings.

Distributed under creative commons license 4.0
The number two (Er), is an auspicious number in Chinese culture, because there is a Chinese saying "good things come in pairs". So at wedding celebrations, decorations are invariably laid out in pairs: a pair of red candles, a pair of pillows, a pair mirrors, a pair of red washbasins, a pair of red towels, a pair red tooth mugs, and couplets hung on two sides of the hall. It often writes like this: "A good marriage lasts forever and a happy heart is sealed." People will decorate gates and windows with red paper-cuts: 囍 (meaning double happiness), and so on. The red paper-cuts on the windows which are named window flowers in Chinese are also paired. Patterns are a couple of magpies, and a couple of mandarin ducks and a couple of fish on it. Or a girl and a boy together form a beautiful pattern, and Patterns of flowers, and plants which show symmetry are pasted on the windows. It is common to use double symbols in product brand names, e.g. "Double Happiness" table tennis bat, "Double lion" tile, "Double fish" table tennis table, etc. ${ }^{[2]}$.

Six, pronounced as 'Liu', and similar to "fluid" ( 流 ) and conveys the meaning - Do everything smoothly, 6 is therefore considered good for business. It is the common figure in business, for example, "6 habitat" pickles, "6 Harmony and smoothness" restaurant etc.. in people's phone number, QQ number, license plate number, house number and wedding date, $6 \mathrm{~s}$ are also popular.

And eight, "8" and "Fa in Cantonese have similar pronunciation which means to get rich. Thus all business men favor this number very much. People like to select it to their telephone number, car registration plates, etc. The opening ceremony of the Summer Olympics in Beijing began on $8 / 8 / 2008$ at 8 seconds and 8 minutes past 8 pm (local time).

The number five $(\mathrm{Wu})$ is associated with the five elements (water, wood, fire, earth and metal) in Chinese philosophy, which ancient Chinese philosophers used the theory of five elements to explain the formation and interrelationship of all things in the world. It emphasizes the whole concept, aims to describe the movement form and transformation relationship of things, and is regarded as the foundation of the world. The Chinese also say that "five blessings come to the door", which means: the first is longevity, the second is wealth, the third is health and peace, the fourth is good virtue, and the fifth is to die a natural death. Some people call it longevity, richness, health, virtue and goodness for short. Only when the five blessings are combined can a happy and satisfactory life be formed. And it was historically associated with the Emperor of China. "Nine" and "Five" symbolize the authority of the emperor, which is called "the Ninth Five".

DOI: https://doi.org/10.26549/jetm.v4i2.3869 
Seven (Qi) is a lucky number in Chinese culture, because it sounds alike to the Chinese character 起 meaning arise and together. It is also recognized as the luckiest number in the West, and is one of the rare numbers that is great in both Chinese and many Western cultures.

Nine(Jiu), being the greatest of single-digit numbers, was historically connected with the Emperor of China.The Emperor's robes often had nine dragons, Emperor's place of residence has nine dragons posts and nine dragons wall. Thus, it is said that there were 9999.5 rooms within the Forbidden City in Beijing. Moreover, the number 9 is a homophone of the word for "long-lasting" ( 久 ), means longevity and eternality, and as such is often used in weddings. It is also a tradition between lovers to send 99, or 999 roses, which carry the best wishes for "everlasting love". Chinese Taoism also has the saying of "jiuxiao": nine clouds/heavens and the ninth heaven where the immortal lives. It is similar to the seventh heaven in the west, jiuxiao is also the highest heaven, the highest sky. For example, Mao Zedong's poem " "Butterfly Loves Flowers and Answers to Li Shuyi": I lost my dear wife: Yang Kaihui, and you lost your husband: Liu Zhixun The spirits of the two of them float gently to the deep and wide sky/heaven.

However four, is considered an unlucky number in Chinese culture as it sounds like "Si" (death). So when people choose car license tags, phone numbers, and room numbers, they try to avoid it. In Hong Kong, some highrise residential buildings miss all floor numbers with " 4 ", e.g. 4, 14, 24, 34 and all 40-49 floors.

In the West, 3 and 7 is considered as the most favorable auspices. In western culture, the world is made of the land, the sea and sky, the nature is made of animals, plants and minerals. So the westerners like the number of 3 . And they love 7 best because there are seven days in the world and after the God created all things, he had a rest in the seventh day in the Bible. Christianity has the theory of Seven Heavens, Seven Heavens are: pure silver, pure gold, pearl, white gold, white silver, ruby and the guardian angel. The seventh heaven is a paradise, the dwelling place of God and the highest angel. This theory is the same as the nine clouds (or heavens) in the sky of Chinese tradition. Therefore, the West likes 7 most, so July 7, 2007 is considered the most auspicious day, and many Westerners get married. Western brand names also like to use this number, such as "7 up", which is translated into "7 happiness" in Chinese, which is really a very festive name. And rainbow has seven colors, music has seven levels.

However, the number 13 is considered the most unfortunate number in the West. Many hotels and tall build- ings don't have a 13th floor or a Room 13. Never have 13 dinner guests at table or terrible things will happen! Westerners believe the person sitting on the last chair will die. This mainly comes from the Last Supper where Jesus and his twelve disciples sat to eat the meal, which made up the number 13. Judas sold his master for thirty pieces of silver. Jesus was killed by nailing on the cross the following day on a Friday. That's why Westerners are afraid of Black Friday and the number 13. If it happens to be Friday, Westerners will not go out.

\section{Table Manner}

As a country that pays great attention to courtesy, Chinese cuisine culture is deep rooted in China's history. As a visitor or guest in either a Chinese home or restaurant you will find that table manners are essential and the distinctive courtesies displayed will invariably add to the enjoyment of your meals and keep you in high spirits!

In China, it is a custom to respect others at the table, including the aged, teachers and guests while taking good care of children. Chinese people stress filial piety all the time. The table manner of presenting the best or fine food first to the senior members of the family has been taken into granted. The main dishes are prepared in a decorative form to place facing the major guests and elder people at the table.

Why do Chinese people emphasize filial piety? Because everybody gets old, everyone has no strength, no capability and lies in the bed and needs being looked after by others someday. If you are discriminated, abandoned and abused, you will feel desperation. So as a Chinese saying, if you would not be treated like this, you should respect and be kind of old people. Chinese people also say if you love your grandparents and you should also love others' old people and if you love your child and you should love others' children, too. Therefore we should love old people and children. In addition, we love old people for the purpose of selfishness. We hope we will be well- treated in the future. We have a Chinese historical story that a father disfavored his old father and thought he was useless and decided to abandon him. He put him in a big basket with his son and went into the forest and he left him in the forest and plans to leave. His son asked him why he left his grandpa behind and he said to his son he was no use and left him to die. His son said no a word and brought the big basket and planned to leave. His father asked him why he took the basket? His son said I would use this basket to take you to come here when you are old. His father listened to his words and felt shocked in a cold sweat. He realized the truth suddenly and brought 
his father back home and took good care of his father and his son was very happy and his family lived a harmonious life. In ancient times the common people led a needy life but they still tried their best to support the elder mother or father who took it for granted. And rulers advocate this like Emperor $\mathrm{Wu}$ of Han he once ordered people killed owls because the birds eats his mother and the owls were thought as an unfilial bird. Although a person would often bring up his own children, he maybe would not support his parents because their old ages and uselessness as people think. In fact, supporting our own parents is the biggest kind-hearted for both themselves and their parents. Old people are very useful because they have rich life experience and knowledge and give us precious suggestions. So Chinese people advocate that people should love their parents and respect the old people. This is the real source of the civilization of human being. This is the proof of the existence of Chinese civilization in thousands of years ${ }^{[2]}$.

Why do Chinese people respect their teachers? Because teachers give students some advice and arouse their consideration and spur them to ask questions and find out the answers according to their knowledge they learned and experience they went through. It takes a teacher to transmit wisdom, impart knowledge and resolve doubts according to Chinese ancient classic article. First of all, they want to transmit wisdom to students in order to protect their safety. In Chinese ancient time, when a mentor only taught his knowledge and skills and didn't care about how to be a man to his apprentice, he will starve to die if his apprentice replace his position or own his skills. So a Chinese mentor lets his apprentice do chores in three years in order to inspect his moral quality. If he is reliable, the mentor teaches his real capability. Don't cut down the tree that gives you shade. So virtue is the most important quality. In the modern time, teachers have the responsibility to teach their students' service heart, the sense of responsibility for their benefits. If the society is comparative fair, everybody will be conscientiously unscrupulous in the fulfillment of his duty, you can be safe in most circumstance and few hostility to the rich. Teaching a child is a very difficult thing, so we should respect teachers. But we also should listen to the child's words. Children are the teachers of the human being according to the Maria Montessori just as the above story mentioned. It is the son who teaches his father how to be a man. Maria Montessori is the first woman to find the secret. Another example, as all people know about the story of new clothes of the emperor. In the story, most people pretend to have seen the new clothes of the emperor in order to avoid being said to be foolish. Only the little boy tells the truth. So we should turn it around our teaching methods. Students should be encouraged to ask questions and find out the answers by themselves and given them suggestions by teachers. If they can't find the answers, they can consult to the teachers or the internet or solve them in the future. Listen to the children carefully and they are our teacher ${ }^{[3]}$.

Why do Chinese people respect guests? They bring us new ideas, new ways and new culture. So we welcome to them.

In addition, during a meal, it is considered rude and a sign of bad luck to leave chopsticks sticking up in the bowl. Try not to drop your chopsticks either, as this, too, is a sign of bad luck.

Avoid putting your hands in your mouth for any reason while at the table. If you must take something out of your mouth, such as bones, gristle, or another item, use a toothpick.

Do not take the last piece of food on the serving platter. It's considered to show your greed.

Always offer food or tea to someone else before you serve yourself. You would be considered without manners if you serve yourself first.

Perhaps a Western visitor most surprised that some of the Chinese hosts like to put food into the plates of their guests with their chopsticks. In formal dinners, there are always "public" chopsticks and spoons for this purpose, but some hosts may use their own chopsticks. This is a sign of genuine friendship and politeness. It is always polite to eat the food. If you do not eat it, just leave the food in the plate.

In the west, you never cross your cutlery on your plate when you've finished eating. This could indicate that your meal was poisoned and you would die from this.

- Never turn your bread upside-down. Bread is considered as the staff of life and turning it upside-down means death will come to someone at the table.

-Never spill the salt. Salt is a sign of friendship, spilling it means disagreement and the loss of a friend.

-Always destroy your empty egg shells. It was thought that magicians would use them to make evil spells. Crushing the shell meant you were destroying the magic.

-If you drink the last wine in the bottle, you shall marry within the year. If you are already married, it means you will have a daughter within a year (not be arrested for bigamy!).

-If you spill wine, this is a good thing (some would disagree!) Romans would spill wine over the table before a meal to honor their gods. 


\section{Festival}

If we want to understand the culture of a nation, we must do it from the traditional festival.

Chinese and British festivals and customs have obvious differences. Chinese festival is mainly a wish for their family members, relatives and friends' longevity and health, richness, good luck and happiness. British festival mainly comes from religion and related events, memory, and god bless.

As a great agricultural country, Chinese culture is deeply rooted in agriculture. So it attaches great importance to the influence of climate on crops. The spring is the season to plant and autumn is to harvest. Some festivals have formed from these. Some ancient festivals would celebrate the end of cold weather, and plant in spring. Spring Festival also called the Chinese New Year is the most important festival in China. The celebration of the Chinese New Year begins from the eighth of the twelfth lunar month of an old year to the fifteenth of the first lunar month of a new year. By tradition, Chinese will be busy buying presents, decorating their houses, preparing food and making new clothes for the New Year. During that period, all transportation, in particular the railway will be busy taking Chinese back to their home town for the Chinese New Year Eve family reunion.

Days before the New Year, all families thoroughly clean their homes, hoping to sweep away all the ill-fortune in order to make way for good luck. People repaint their home. They decorate the doors and windows with red paper-cut and couplets having very popular themes such as "happiness", "wealth", "longevity" and "satisfactory marriage with more children". Paintings of the same theme are put up in the house on top of newly mounted wallpaper.

The New Year Eve supper is a feast, all family members will come together. The feast is different in the south and the north. The southerners will eat Tangyuan that mean happy reunions because of ball shape, another kind of dumplings made of sticky rice rolled into balls and stuffed with fillings while the northerners will eat Jiaozi, that which used to be a good wish for a family. Jiaozi is a homonym for Jiaozi, that is, the moment when the new year and the old year intersect. Eating dumplings during the Spring Festival means the most favorable auspices. In addition, the shape of dumplings is like a silver ingot and making dumplings means wrapping good luck. People also have fish, meat, and vegetable. After dinner, it is time for the whole family to sit up for the night while having fun playing cards or board games or watching TV pro- grams: CCTV New Year's Gala which specially made for the occasion. Light will be kept on the whole night. When the clock strikes twelve, firecrackers will set off and is the mark of the New Year ${ }^{[4]}$.

Very early the next morning, children will greet their parents and will receive lucky money wrapped with red paper from their parents. Then, the family will start out to pay New Year calls from door to door, first their relatives and then their neighbors and friends. People will exchange gifts. The New Year lasts fifteen days until the Lantern Festival sets in. It is an occasion of lantern shows and folk dance everywhere, especially lions and dragons dance around. One typical food is Tangyuan also called Yuanxiao as mentioned above.

In Britain, religion is a social and cultural center, and it exists in all walks of life. Therefore, festivals like Christmas, and Easter are closely related with religion.

Before the Christmas, people buy presents, and decorate their house with color lights and Christmas tree. On the Christmas Day, children get up very early in the morning to find their stockings have been filled by Father Christmas and excitedly open the gifts before going down to breakfast. Family get together to open the presents found under the Christmas tree either late morning or during the afternoon.

Many Christians will put on their best clothes to the church to sing carols and to celebrate the birth of Jesus.

The whole family members sit down for Christmas dinner at mid-day or early afternoon. A traditional Christmas dinner involves roast turkey or goose, roast potatoes, tiny sausages wrapped in bacon (pigs in a blanket), vegetable and pudding doused in flaming brandy said to ward off evil spirits. It's a Christmas tradition that when you eat a turkey, you get a little piece of the "Y" wishbone on the turkey breast, you hold one end of the wishbone, you make a silent wish, and then you pull it, and the other person do the same and the person who leaves the larger bone gets his wish. This bone is called wishbone. Then came up the Christmas pudding, where each family member traditionally made a pudding together, symbolizing unity and harmony, and each stirred the dough, acquiescing to a wish, and finally hiding a coin in the dough. Whoever finds a silver dollar in his Christmas pudding while eating it will have good luck for a year. The traditional Christmas pudding is made by preheating the brandy in a small pot, then lighting the brandy, pouring the lighted brandy over the Christmas pudding, and wrapping the Christmas pudding in a blue flame, bringing the festive atmosphere of the Christmas celebration to a climax! It's said to ward off evil spirits. Christmas is celebrated in the UK with the 
Christmas cracker, an integral part of the British Christmas celebrations. The popular Christmas cracker is a cardboard tube shaped like a very large piece of fruit candy. Two people each pull a head, when the cylinder broke out of a small explosion. The person with the big head gets a small gift, which usually includes a paper hat whose shape looks like a crown, a small toy, a note with a joke, riddle, a brain-teaser question, or a little story. After a Christmas party or a Christmas dinner, people usually pull the Christmas cracker. The pulling of Christmas crackers often accompanies food. Then people wear paper hats. Early evening they have a Christmas Tea.

At three o'clock in the afternoon, the Queen delivers her Christmas message to the nation and the Commonwealth, which is broadcast on radio and television. They drink Christmas tea in the evening.

The origin, food, customs and activities of Chinese and British festivals are different.

\section{Animal Differences}

In the long historical development, same animals have different cultural connotation between Chinese and English. For example, in Chinese fish has auspicious meaning because fish and "Yu" are homophonic. There is a Chinese idioms: "every year has fish".(Every year has enough to spend.) So in the spring festival feast, Chinese must have fish on the table. However, fish in English has derogatory color, generally describe the bad thing or people, for example a poor fish, a loose fish, a cool fish, a strange fish, etc. ${ }^{[5]}$.

Westerners think bats are evil, ugly, vampire-like animals, so they fear them. But in traditional Chinese culture, bats are the mascot, because "Bat" and "Fu" (happiness) is homophonic, also homophonic "Fufu", a symbol of happiness, meaning endless, so. Bats in many of the remaining ancient buildings, as well as brick engravings, stone carvings can be seen almost everywhere. The ancient silk and brocade, the clothing, the jewelry, the utensil often use bat patterns, for example: "The blessing falls from the sky" : which is formed by bats and auspicious clouds pattern. " The mind becomes intelligent at the approach of happiness " which will be carved together with the bats, longevity peaches and Ganoderma lucidum. The word "longevity" is carried by longevity peaches. The homonym " Ganoderma lucidum " is "Zhi", the meaning of "reach". The peach is like the shape of "heart", and the Ganoderma lucidum is also the symbol of intelligent. "Fu Shou Shuangquan"means both fortune and longevity which put bats, longevity peaches and two ancient coins together, and "coins" means "all" and "two" means "double" and so on.

The dog in English in most occasions is commendatory terms, for example, "help a dog over a still", "a lucky dog", "Every dog has his day." In Chinese the dog with the derogatory color, such as Chinese idioms: like a dog threatening people on the strength of its master's powerbe a bully with the backing of a powerful person, "wolf's heart and dog's lung" means ungrateful, "the dog's gallbladder dare to wrap the sky-daredevil, a running dog (flunky), etc..

In China, the Magpie is considered to be "reporting good luck", which is a symbol of good luck and good fortune. People say, "when the magpie cries, good things will come. " Painters like to draw "Magpie on Plum Branch Reporting Good News", also known as "happy eyebrow. " which foresees that a man keeps going up, the family rises to prominence. But in English, the magpie is a symbol of boredom and talks endlessly.

In English, owl is a clever and witty bird, and thus has the cultural connotations of "shrewdness, wisdom", such as, wise as an owl. But in the eyes of the Chinese people, because of its frightened, nocturnal cries, it is considered unlucky. And someone will be dead when it cries. As long as the night owl is found in or around the house, it will be immediately driven away or killed. Owls have the habit of eating mother. They are unfilial birds and people hate them very much. So people say: "The owl goes into a house, what something happens, especially bad things"

It is interesting that different animal words have similar cultural connotations in Chinese and English cultures. For example, Chinese say play the lute to an ox-address the wrong audience. English say: "Cast pearls before swine." In terms of "big talk ", Chinese say "brag cow", but in English, but with "talk horse". Chinese use the idiom of "timid as a mouse" to describe the timid. In English, however, rabbit, chicken, and pigeon are used as analogies, such as: as timid as a rabbit, chicken-hearted, or pigeon-hearted. Chinese say "hot pot ants", but English say "like a cat on hot bricks. ( hot bricks on the cat.) "In Chinese, cattle are generally describe strength whereas English uses horse, such as he is an as strong as a horse. Chinese general "pig" refers to the fool, such as stupid like a pig. While English was used to express the meaning of ass, such as make an ass of oneself. Chinese people regard tigers as the king of beasts, people often use "tiger" to describe the mighty and fierce. While in English, the mighty image is the lion, such as: as bold as a lion. In English, people say: "like a drowned rat." In Chinese, people say: "like a chicken falling into the soup." English say: "like a rat in a hole", Chinese say: "catch a turtle in a big jar." 
English say: "Kill two birds with one stone." Chinese say: "Shoot two hawks with one arrow." English say: "When the cats are away, the mice will play." Chinese say: "If there is no tiger in the mountain, the monkey will call the king." English says: "Love me, love my dog." Chinese say: "Love my house, love the crow on my house."

This paper shows the importance of cultural education in English teaching, also makes some comparisons between Chinese and English cultures. There are obvious cultural differences because of history, tradition, and customs of two languages. So understanding these cultural differences helps us teach good English, also helps Chinese communicate with English-speaking people very well.

\section{References}

[1] Li, Ruihua. A Contrastive Study of English and Chi- nese Language and Culture [M]. Shanghai: Shanghai Foreign Language Education Press, 1996.

[2] Yu, Qi. Festival Comparison among the World [M]. Shanghai: Shanghai Foreign Language Press, 2001.

[3] Zhao, Baoguo and Tan, Xiaorong.21st Century Practical English for Tourism [M]. Shanghai: Academia Press, 2005.

[4] Shi, Aihua and Gu, Baozhu. English for Tourism [M]. Beijing: China Machine Press, 2012.

[5] Zhou, Guanqiong. A study of college English Teaching in the Context of Cultural Differences between China and the West $[\mathrm{M}]$. Beijing: China Water Power Press, 2016. 